\title{
Assessment of Aridity Using Geographical Information System in Zayandeh-Roud Basin, Isfahan, Iran
}

\author{
Maryam Marani-Barzani ${ }^{1}$, Saeid Eslamian², Mahboubeh Amoushahi-Khouzani ${ }^{3}$, \\ Amir Gandomkar ${ }^{4}$, Foroozan Rajaei-Rizi ${ }^{5}$, Masoud Kazemi ${ }^{6}$, Shahide Dehghan ${ }^{7}$, \\ Vijay P. Singh ${ }^{8}$, Hossein Norouzi ${ }^{9}$, Hamid-Reza Shirvani-Dastgerdi ${ }^{10}$, Amin Sadri ${ }^{11}$, \\ Kaveh Ostad-Ali-Askari ${ }^{12} *$ Nicolas R. Dalezios $^{13}$, Morteza Soltani ${ }^{14}$, \\ Khairulmaini Bin Osman Salleh ${ }^{15}$, Yohannes Yihdego ${ }^{16}$, Zahra Askari ${ }^{17}$ \\ ${ }^{1}$ Department of Geography, University of Malaya (UM) ,50603 Kuala Lumpur, Malaysia. \\ ${ }^{2}$ Department of Water Engineering, Isfahan University of Technology, Isfahan, Iran \\ ${ }^{3}$ Water Engineering Department, Science and Research Branch, Islamic Azad University, Tehran, Iran \\ ${ }^{4,7}$ Department of Geography, Najafabad Branch, Islamic Azad University, Najafabad, Iran \\ ${ }^{5}$ Water Engineering Department, Shahrekord University, Shahrekord, Iran \\ ${ }^{6}$ Civil Engineering Department, Najafabad Branch, Islamic Azad University, Iran \\ ${ }^{8}$ Department of Biological and Agricultural Engineering \& Zachry Department of Civil Engineering, Texas A \\ and M University, 321 Scoates Hall, 2117 TAMU, College Station, Texas 77843-2117, U.S.A. \\ ${ }^{9}$ Faculty of Civil Engineering, Maybod Branch, Islamic Azad University, Maybod, Yazd, Iran \\ ${ }^{10}$ Department of Civil Engineering, Isfahan (Khorasgan) Branch, Islamic Azad University, Isfahan, Iran \\ ${ }^{11}$ Water and Wastewater Company, Isfahan Province, Isfahan, Iran \\ ${ }^{12 *}$ Department of Civil Engineering, Isfahan (Khorasgan) Branch, Islamic Azad University, Isfahan, Iran \\ ${ }^{13}$ Laboratory of Hydrology, Department of Civil Engineering, University of Thessaly, Volos, Greece \& \\ Department of Natural Resources Development and Agricultural Engineering, Agricultural University of \\ Athens, Athens, Greece \\ ${ }^{14}$ Department of Architectural Engineering, Shahinshahr Branch, Islamic Azad University, Shahinshahr, Iran \\ ${ }^{15}$ Department of Geography, University of Malaya (UM), 50603 Kuala Lumpur, Malaysia \\ ${ }^{16}$ Snowy Mountains Engineering Corporation (SMEC), Sydney, New South Wales 2060, Australia. Geo \\ Information Science and Earth Observation (ITC), University of Twente, the Netherlands \\ ${ }^{17}$ Water Engineering Department, Ferdowsi University of Mashhad, Mashhad, Iran
}

*Corresponding Author: Dr. Kaveh Ostad-Ali-Askari, Department of Civil Engineering, Isfahan (Khorasgan) Branch, Islamic Azad University, Isfahan, Iran.Email: Koa.askari@ khuisf.ac.ir

\begin{abstract}
Rapid growth of population and human activities has caused a perceptible change in the climate in some parts of Zayandeh-Roud Basin (Z.R.B.). High temperatures and aridity in some parts are a growing environmental problem. Assessment and monitoring of aridity is essential to protect desertification and mitigate drought. A Geographical Information System (GIS) was used in this paper for the assessment of (Z.R.B) using climatic data collected from 11 stations situated in the basin. In order to assess aridity, three well-known aridity models, viz. De Martonne Aridity Index, Thornthwait Precipitation Effectiveness index and UNESCO Aridity Index, were used. Result showed that climate of Z.R.B is mostly becoming drier. There exists a small climatically wet zone in the area.
\end{abstract}

Keywords: Zayandeh-Roud basin, UNESCO, geographical information system, Aridity Index 


\section{INTRODUCTION}

Drought has long been known to impact people's living conditions and is being alleged to be increasing in frequency due to climate change. In the past, dry lands recovered from long droughts and dry periods. Under modern conditions, however, they tend to lose their biological and economic productively quickly, unless they are managed in a sustainable manner (GOI, 2001). It is difficult to recover when aridity or dryness of an area increases beyond a certain level. The study of dryness of an area is essential to mange land degradation and desertification. Measurement of aridity is important for assessing drought vulnerability, evaluating drought severity, monitoring climate change, assessing bio-environment, monitoring soil moisture, and planning agriculture (Shahid, et.al. 2010). Hence, it is important to have updated dryness maps for planning and management. Geographical information System and climate data are used in this paper for the mapping of aridity or dryness of Z.R.B. from long- term climatic data.

Climate of (Z.R.B.) is characterized by high temperature, low rainfall spatially in large parts east of the area. Different places in the basin have different climates. On the basis of climatic condition, Consultant Engineering (1997) divided Z.R.B. into seven distinct climatic zones. However, different methods were used for the classification of climate. Recently, there has been a serious concern on the extent of aridity in the basin and nowadays development of drought in the area is a serious issue. Rapid growth of population and human activities along with industries, construction, modification of landforms and decline of ground waters have been impacting the biophysical environment of the region and this has also caused a noticeable change in the climatic condition of the basin. The aim of this paper is to get a comparison of standard methods and reliable picture of aridity of Z.R.B.

A number of methods have been used for mapping aridity of an area. The methods are based on precipitation and temperature; precipitation, evaporation, and relative humidity; number of dry days; and precipitation-evapotranspiration ratio. Among these methods, the precipitation-temperature based method, proposed by De Martonne (1926), is widely used for measuring aridity of an area. Another widely used method is Thornthwaite's method (Thornthwaite, 1931) based on precipitation and temperature. UNESCO (1979) has proposed a rainfall-evapotranspiration ratio based method for the estimation of dryness. In this paper all the three methods are used for the aridity mapping of Z.R.B.

\section{STUdy AREA}

The Zayandeh-Roud Basin (Z.R.B.) is located in the central part of Iran with a longitude of $52^{\circ} 1^{\prime}$ to $52^{\circ} 7^{\prime} \mathrm{E}$ and a latitude of $32^{\circ} 36^{\prime}$ to $32^{\circ} 40^{\prime} \mathrm{N}$ (Figure 1). The maximum precipitation in the basin occurs during winter in January and February, while the minimum is during summer in July and August. The average annual precipitation is $105.84 \mathrm{~mm}$, the average annual temperature is $14.9^{\circ} \mathrm{C}$ and the average evaporation is $2,219.3 \mathrm{~mm}$. (Khodagholi, 2006). The most important factors during a drought in the basin are geographical location, non-normative exploitation of the surface mineral of gypsum, non-normative exploitation of land, reduced entrance of runoff from upstream regions, a sharp drop in the groundwater level, winds, and storms laden with chalk, dust and suspended particles, low precipitation, and high evaporation.

In this region, precipitation starts when high-pressure-air massif on the Iran plateau moves to lower latitudes. In Z.R.B., rain starts in the middle of October and continues into May, while the source of rain is the Mediterranean cyclone. However, in some areas, regional cumulus clouds cause squall in late spring and summer; in the mountainous areas, this causes rain. Data show that rainfall varies greatly from area to area so that some areas receive 20 times more rain than do other regions. The average annual precipitation in the low land (around GAV KHOONI marsh) is about $72 \mathrm{~mm}$, while it is more than $1,550 \mathrm{~mm}$ in high altitudes and western heights. The average annual precipitation is about $2,095 \mathrm{~mm}$. The maximum annual precipitation recorded is about 2,375 $\mathrm{mm}$ at CHELGERD station in the northwest and the minimum annual rainfall is about $25 \mathrm{~mm}$ in the east in MOORCHEH KH ORT. 


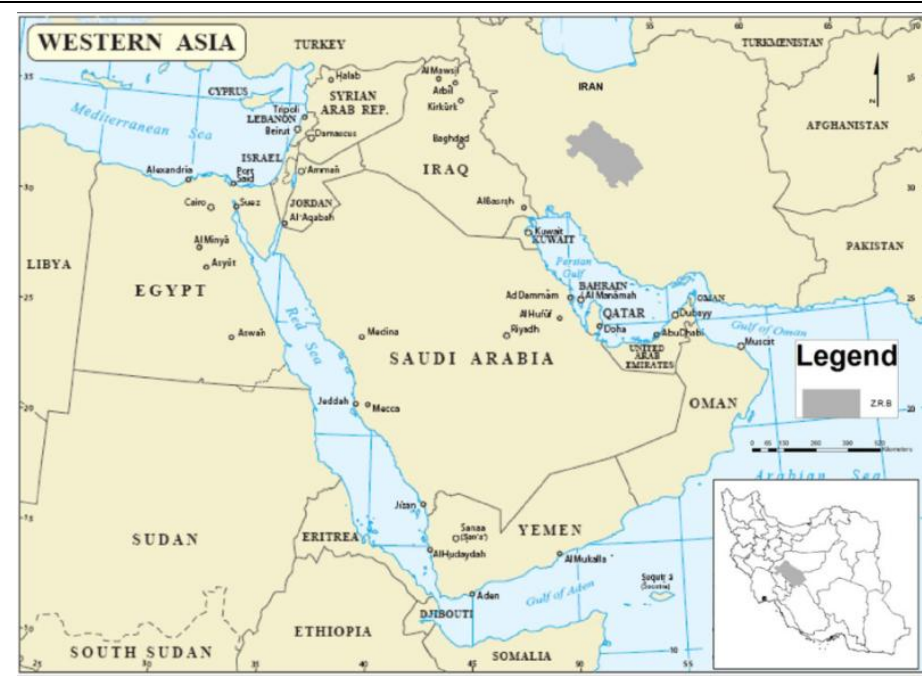

Figure1. Location of Z.R.B. in Iran (Maryam M. B., Khairulmaini O S, (2013)

\section{Aridity Measuring Models}

For the aridity index mapping of Z.R.B. three aridity-indexes, namely De Martonne's aridity index, Thornthwait's precipitation effectiveness index, and UNESCO aridity index, were used. Each index is given below:

De Martonne's Aridity Index

This index can be expressed as

$A I=\left[P /(T+10)+12_{P} /(t+10)\right] / 2$

where:

$P$ is the mean annual precipitation in $\mathrm{mm}$,

$T$ is the mean annual temperature in $\mathrm{C}^{\circ}$,

$P$ the precipitation of the driest month in $\mathrm{mm}$, and

$t$ the mean temperature of the driest month in $\mathrm{C}^{\circ}$

According the AI value, De Martonne (1926) classified the climate into six types, namely, arid, semiarid, dry sub-humid, moist sub-humid, humid, and very humid. Classification of dryness based on De Martonne's aridity index is given in Table 1.

Thornthwaite's Precipitation Effectiveness

Thornthwaite (1931) defined precipitation effectiveness index (PE), which is calculated from monthly values of precipitation and temperature. The index is given as:

$P E$ Index $=\sum_{1}^{n=12} 115 *(P /(T-10))^{10 / 9}$

Where, $\mathrm{P}=$ monthly precipitation in inches;

$\mathrm{T}=$ temperature in $\mathrm{F}^{\circ}$; and

$\mathrm{N}=$ months $=12$.

The classification of climate regions is based on Thornthwaite's precipitation effectiveness index, as shown in table 2.

UNESCO aridity index

The UNESCO (1979) proposed a method for aridity mapping from the ratio of precipitation (P) to potential evapotranspiration (PET), i.e.,

$A I=P / P E T$

where PET is calculated by Penman's formula.

Based on the AI values, five climate regions of aridity are proposed, as shown in Table 3. 


\section{MAPPING ARIDITY OF ZAYANDEH ROOD BASIN}

The aridity mapping of Z.R. B. is carried out from the climate data of 11 hydrometeorological stations situated in and around the area. The data obtained from meteorological organization of Iran were used in this paper. Locations of climate stations are shown in figure 2 . The aridity mapping is carried out by incorporating the aridity measuring models in a geographical information system. Procedures of mapping using De Martonne's, Thornthwait and UNESCO methods are shown in Figures (3), (4) and (5).

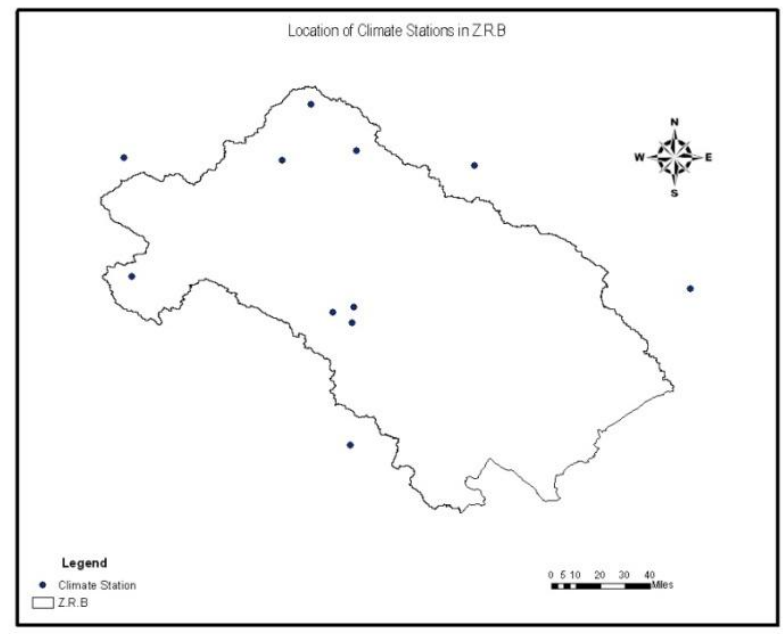

Figure2. Locations of Climate Stations in Z.R.B

De Martonne's aridity modeling carried out by calculating the mean annual precipitation and temperature, and the driest month of the year was identified from monthly mean climate data. Thematic maps of mean values of annual precipitation and temperature, and precipitation and temperature of the driest month were obtained from the average of sixty-years of climatic data of 11 stations using the kriging method. The thematic maps were integrated by using the index equation. Finally, the AI values were classified into different layers following the ranges given in Table 1 to prepare De martonne's aridity index map of Z.R.B., which is shown in Figure 3.

Table1. Classification of dryness based on De Martonne's Aridity Index (De Martonne, E., 1926).

\begin{tabular}{|c|c|}
\hline Climate Class & AI Value \\
\hline Arid & $\leq 5$ \\
\hline Semi-arid & $5-12$ \\
\hline Dry Sub-Humid & $12-20$ \\
\hline Moist sub-Humid & $20-30$ \\
\hline Humid & $30-60$ \\
\hline Wet & $\geq 60$ \\
\hline
\end{tabular}

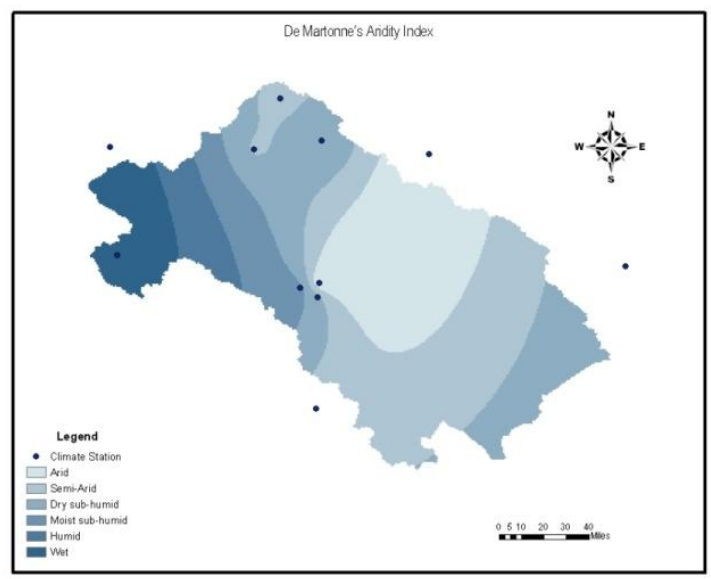

Figure3. Dryness map of Z.R.B. carried out by using De Martonne index 
Assessment of Aridity Using Geographical Information System in Zayandeh-Roud Basin, Isfahan, Iran

For Thornthwait's aridity modeling, first the PE index values for all the 11 stations were calculated. The PE values were krigged and classified following the ranges given in Table 2 to prepare the thematic map of Thornthwait's precipitation effectiveness index of Z.R.B., which is shown in Figure 4.

Table2. Classification of the dryness based on Thornthwait's Aridity Index (Thornthwaite, C.W., 1931)

\begin{tabular}{|c|c|}
\hline Climate Class & AI Value \\
\hline Arid & Greater than 128 \\
\hline Semi-arid & $100-127$ \\
\hline Dry Sub-Humid & $64-99$ \\
\hline Moist sub-Humid & $32-63$ \\
\hline Humid & $16-31$ \\
\hline Wet & Less than 16 \\
\hline
\end{tabular}

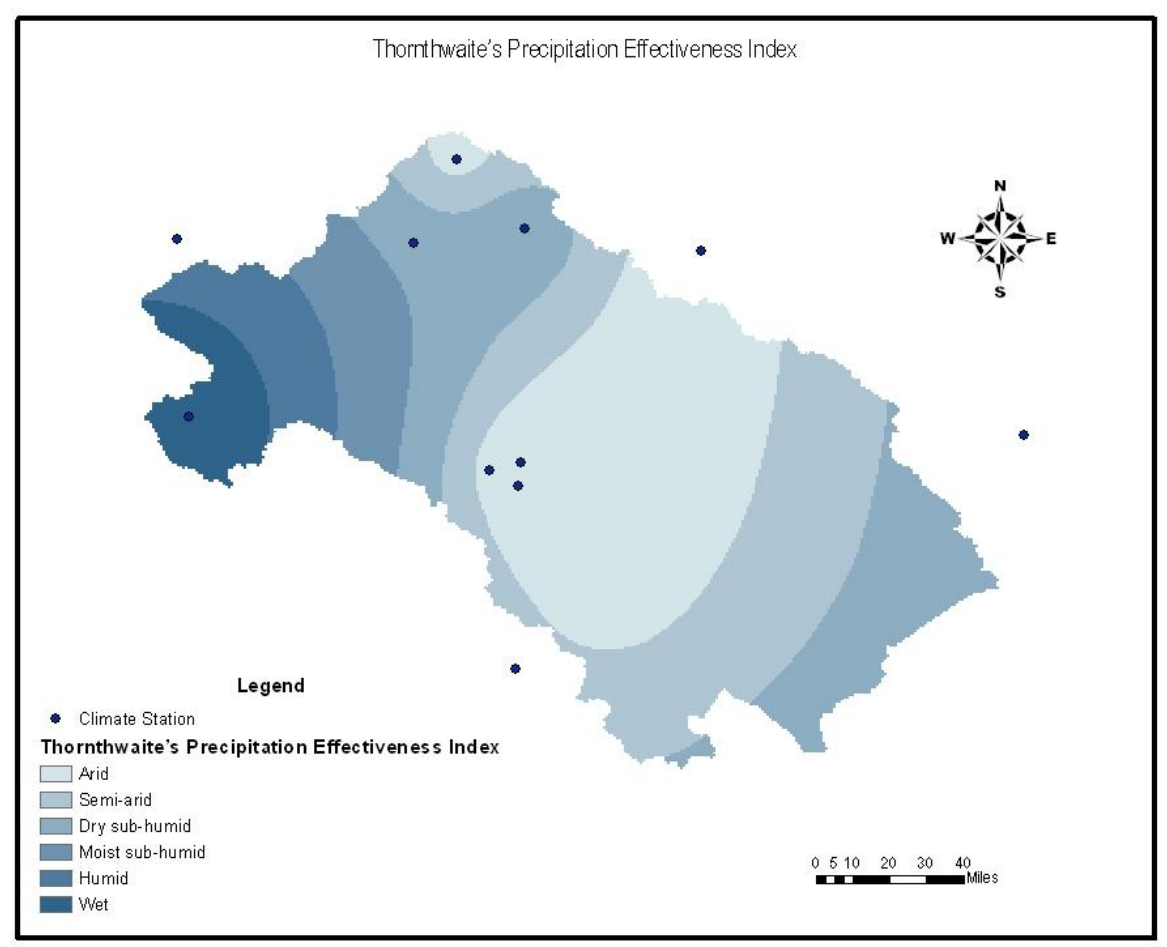

Figure4. Dryness map of Z.R.B. carried out by Thornwait's index

In the UNESCO aridity index modeling, first the potential evaptranspiration (PET) was calculated at 11 climate stations using Penman's formula. The PET and precipitation values were used to make the thematic maps of PET and precipitation using the krigging method. Finally, the maps were integrated and the generated aridity index values were classified using the ranges given in Table 3 to develop the UNESCO aridity index map of Z.R.B. (shown in Figure 5).

Table3. Classification of dryness based on UNESCO's Aridity Index (UNESCO, 1979)

\begin{tabular}{|c|c|}
\hline Climate Class & AI Value \\
\hline Hyper Arid & $\leq 0.03$ \\
\hline Arid & $0.03-0.2$ \\
\hline Semi-arid & $0.2-0.5$ \\
\hline Dry sub-humid & $0.5-0.65$ \\
\hline Humid & $>0.65$ \\
\hline
\end{tabular}




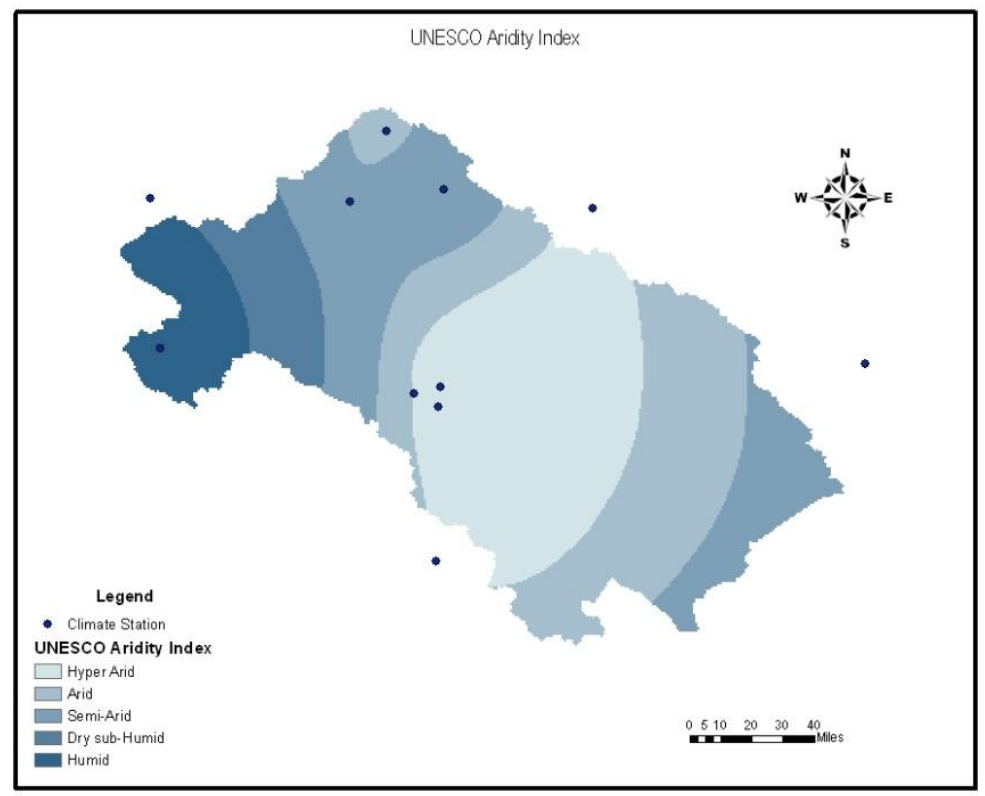

Figure5. Dryness map of Z.R.B. carried out by UNESCO index

\section{RESULTS AND DISCUSSION}

The aridity index maps were prepared using De Martonne's, Thornthwait's and UNESCO indexes that occur on arid, semi-arid or dry sub-humid zones in Zayandeh Rood basin. Most of the area of Z.R.B. belongs to the dryness class except for some parts on the northwestern side which belongs to the wet class. The statistics of aridity index values obtained by using the three models are given in Table 4. The least AI values obtained by De martonne's, Thornthwait's, and UNESCO models were 20.89, 64.04 and 0.98, respectively, in the central-western and northwestern parts of Zayandeh Rood basin. As the AI values in the region were lose to the AI value of the dry zone, the climate of these regions of Z.R.B. can be said very close to dry. The total annual evapotranspiration in this region was also lower than or equal to annual rainfall. The region which is very close to the dry sub-humid climate is shaded on the aridity maps.

Based on the maps, climate in the central eastern, southeastern, northeastern and north side of the area was close to dry climate. However, the climate of the area was inching towards more dryness. Rapid population growth and human activities with land use in the region have been degrading the biophysical environment and consequently changing the climate of the region. Rainfall has decreased and the high temperature between the hot daytime and cooler late night has increased. Since the area has low rainfall, extraction of groundwater as the main source has increased. It has caused the successive lowering of the groundwater table of the region, which has consequently been greatly affecting the environmental quality and land subsidence.

Sustainable measures like micro-watershed management for the promotion of in situ moisture conservation should be taken in the region. Programs that have relevance to environmental and sustainable development of natural resources have to be expedited. Local people have to be educated and social awareness should be grown about deforestation and its environmental consequences (Shahid, et al, 2010).

Results show that the northwestern side of Z.R.B., which is close to ShahreKord, belongs to the wet climate. The mean annual rainfall in this region is three-times more than the mean annual evapotranspiration. The maximum AI values obtained in this side are 117.84, 139.2 and 23.49 by De Martonne, Thornthwait and UNSECO models, respectively.

Table 5 shows areas belonging to different AI ranges. The climate of $56.84 \%$ to $77.3 \%$ area of the Z.R.B has been identified by different aridity index models as near dry sub-humid, $7.88 \%$ to $23.52 \%$ area as moist sub-humid, $5.16 \%$ to $6.6 \%$ area as humid, and $4.94 \%$ to $7.74 \%$ area as wet. Therefore, it can be said that the climate of the area is mostly dry type, except for a few areas in the northwest of the area. 
Table4. Aridity index values obtained by different models

\begin{tabular}{|l|l|l|l|}
\hline & AI value by different models & Thornthwait & UNESCO \\
\hline & De Martonne & 40 & 6.1 \\
\hline Minimum & 46.95 & 139.2 & 23.49 \\
\hline Maximum & 117.84 & 66.05 & 10.055 \\
\hline Mean & 66.19 & 20.88 & 3.74 \\
\hline Standard Deviation & 17.29 & \\
\hline
\end{tabular}

Table5. Percentages of area belonging to different climate zones as demarcated by models

\begin{tabular}{|l|l|l|l|}
\hline Climate & \multicolumn{4}{|l|}{ Percentage of area by different models } & UhNernthwait & 56.84 \\
\hline & De Martonne & 77.3 & 23.52 \\
\hline Near Dry Sub-Humid & 73.81 & 6.73 & 6.6 \\
\hline Moist Sub-Humid & 7.88 & 5.57 & 7.67 \\
\hline Humid & 5.16 & 4.94 & \\
\hline
\end{tabular}

\section{CONClusions}

Aridity index mapping of the dryness of Z.R.B. has been done by using a geographical information system. Three well-known models are used. Results show that the climate of Z.R.B. is mostly dry. However, some parts on the eastern side of the area have dry climate close to that of dry zone of Iran. Desertification and other environmentally harmful activities in the region might cause a noticeable change and consequent increase of aridity in the region. If the aridity of the area increases, it might cause harm to the environment and ecosystem in the arid region. It is therefore essential to manage the basin in a sustainable, planned manner.

\section{REFERENCES}

[1] Consultant, Engineering, (1997). Surface water resources reports in Govkhooni, Yazd and Ardestan area. Water and Soil Research Organization of Isfahan, Iran (Persian). pp.126.

[2] De Martonne, E., (1926). Aérisme et indice d'aridité. Comptes rendus de l'Académie des Sciences, 182, 1395-1398.

[3] GOI, (2001). Nation Action Programme to Combat Desertification in the Context of United Nations Convention to Combat Desertification (UNCCD), Vol-I: Status of Desertification, Ministry of Environment and Forests, Government of India, New Delhi, September 2001, http://www.unccd.int/actionprogrammes /asia/national/2001/india-eng.pdf

[4] Khodagholi, M. (2006) 'Investigation plants and climate of Zayandeh Rood Basin', Research and Developing Journal, Isfahan, Iran, Vol 50, No. 70. pp,125-132.

[5] Marani Barzani M. \& Khairulmaini O. S. (2013). Desertification risk mapping of the Zayandeh Rood Basin in Iran, Journal of Earth System Science. Indian Academy of Sciences. 122, No. 5, 1269-1282.

[6] Shamsuddin Shahid, et al, (2010). Assessing Aridity in Bangladesh using Geographic Information System, Geospatial World, December 8.

[7] Thornthwaite, C.W., (1931). The climate of North America according to a new classification. Geog. Rev., $21(4), 633-55$.

[8] UNESCO, (1979). Aridity Definition (UN documents), United Nations Educational, Scientific and Cultural Organization, New York.

[9] Ostad-Ali-Askari, K., Shayannejad, M. 2015, Study of sensitivity of Autumnal wheat to under irrigation in Shahrekord, Shahrekord City, Iran. International Journal of Agriculture and Crop Sciences, 8 (4), 602-605.

[10] Shayannejad, M., Akbari, N., Ostad-Ali-Askari, K. 2015, Study of modifications of the river physical specifications on muskingum coefficients, through employment of genetic algorithm. International Journal of Development Research, 5(3), 3782-3785.

[11] Ostad-Ali-Askari, K., Shayannejad, M. 2015, The Reviews of Einstein's Equation of Logarithmic Distribution Platform and the Process of Changes in the Speed Range of the Karkheh River, Khuzestan province, Iran. International Journal of Development Research, 5(3), 3786-3790.

[12] Ostad-Ali-Askari, K., Shayannejad, M., Ghorbanizadee-Kharazi, H. 2015, Assessment of artificial neural network performance and exponential regression in prediction of effective rainfall, International Journal of Development Research, 5(3),3791-3794.

[13] Shayannejad, M. Akbari, N. and Ostad-Ali-Askari, K. 2015, Determination of the nonlinear Muskingum model coefficients using genetic algorithm and numerical solution of the continuity. Int. J. of Science: Basic and Applied Research, 21(1),1-14. 
[14] Ostad-Ali-Askari, K., Shayannejad, M. 2015, The Study of Mixture Design for Foam Bitumen and the Polymeric and Oil Materials Function in Loose Soils Consolidation. Journal of Civil Engineering Research, 5(2), 39-44. DOI: 10.5923/j.jce.20150502.04

[15] Sayedipour, M., Ostad-Ali-Askari, K., Shayannejad, M. 2015, Recovery of Run off of the Sewage Refinery, a Factor for Balancing the Isfahan-Borkhar Plain Water Table in Drought Crisis Situation in Isfahan Province-Iran. American Journal of Environmental Engineering, 5(2): 43-46. DOI: 10.5923/j.ajee.20150502.02

[16] Ostad-Ali-Askari, K., Shayannejad, M. 2015, Developing an Optimal Design Model of Furrow Irrigation Based on the Minimum Cost and Maximum Irrigation Efficiency. International Bulletin of Water Resources \& Development, 3(2), 18-23.

[17] Ostad-Ali-Askari K. Groundwater. Horoufchin publisher, First Edition, 2015. ISBN: 978-600-7419-33-5. Isfahan, Iran.

[18] Shayannejad M, Ostad-Ali-Askari K. Modeling of solute movement in groundwater. Kankash publisher. First edition, 2015. ISBN: 978-600-136-256-9. Isfahan, Iran.

[19] Shayannejad M, Ostad-Ali-Askari K. Optimization and its application in water resources management. Kankash publisher. First edition, 2015. ISBN: 978-600-136-248-4. Isfahan, Iran.

[20] Ostad-Ali-Askari K. Nitrate pollution in groundwater. Horoufchin publisher, First Edition, 2015. ISBN: 978-600-7419-23-6. Isfahan, Iran.

[21] Ostad-Ali-Askari, K., Shayannejad, M. 2015, Presenting a Mathematical Model for Estimating the Deep Percolation Due to Irrigation. International Journal of Hydraulic Engineering, 4(1), 17-21. DOI: 10.5923/j.ijhe.20150401.03.

[22] Ostad-Ali-Askari, K., Shayannejad, M. 2015, Usage of rockfill dams in the HEC-RAS software for the purpose of controlling floods. American Journal of Fluid Dynamics, 5(1), 23-29. DOI: 10.5923/j.ajfd.20150501.03.

[23] Ostad-Ali- Askari, K., Shayannejad, M. 2015, The effect of heterogeneity due to inappropriate tillage on water advance and recession in furrow irrigation. Journal of Agricultural Science, 7(6), 127-136.

[24] Shayannejad, M., Ostad-Ali-Askari, K. 2015, Effects of magnetized municipal effluent on some chemical properties of soil in furrow irrigation. International Journal of Agriculture and Crop Sciences, 8(3), 482489.

[25] Ostad-Ali-Askari K, Shayannejad M, Golabchian M. Numerical methods in groundwater. Kankash publisher. First edition, 2015. ISBN: 978-600-136-276-7. Isfahan, Iran.

[26] Ostad-Ali-Askari, K., Shayannejad, M. 2015, Optimal design of pressurized irrigation laterals installed on sloping land. International Journal of Agriculture and Crop Sciences, ISSN 2227-670X. 8(5), 792-797.

[27] Ostad-Ali-Askari K, Shayannejad M, Eslamian S, Jahangiri A.K, Shabani A.H, Environmental Hydraulics of Open Channel Flows. Kankash Publisher. First Edition, 2015. ISBN: 978-600-136-303-0.

[28] Ostad-Ali-Askari K, Shayannejad M, Eslamian S, Navab-Pour B. 2016, Comparison of solution of SaintVenant equations by characteristics and finite difference methods for unsteady flow analyzing in open channel. International Journal of Hydrology Science and Technology, 6(3), 9-18.

[29] Ostad-Ali-Askari K, Shayannejad M, Eslamian S, et al. 2017, Deficit Irrigation: Optimization Models. Management of Drought and Water Scarcity. Handbook of Drought and Water Scarcity, Taylor \& Francis Publisher, USA. Vol. 3. $1^{\text {th }}$ Edition, pp: 373-389.

[30] Eskandari S, Hoodaji M, Tahmourespour A, Abdollahi A, Mohammadian-Baghi T, Eslamian S, Ostad-AliAskari K. 2017, Bioremediation of Polycyclic Aromatic Hydrocarbons by Bacillus Licheniformis ATHE9 and Bacillus Mojavensis ATHE13 as Newly Strains Isolated from Oil-Contaminated Soil. Journal of Geography, Environment and Earth Science International, 11(2): 1-11.

[31] Shayannejad M, Ostad-Ali-Askari K, Eslamian S, et al. 2017, Development of a new method for determination of infiltration coefficients in furrow irrigation with natural non-uniformity of slope. Sustain. Water Resour. Manag., 3(2): 163-169.

[32] Shojaei N, Shafaei-Bejestan M, Eslamian S, Marani-Barzani M, P. Singh V, Kazemi M, Ostad-Ali-Askari K. 2017, Assessment of Drainage Slope on the Manning Coarseness Coefficient in Mountain Area. International Journal of Constructive Research in Civil Engineering (IJCRCE), 3(1): 33-40.

[33] Bahmanpour H, Awhadi S, Enjili J, Eslamian S, Ostad-Ali-Askari K. 2017, Optimizing Absorbent Bentonite and Evaluation of Contaminants Removal from Petrochemical Industries Wastewater. International Journal of Constructive Research in Civil Engineering (IJCRCE), 3(2): 34-42.

[34] Shayannejad M, Eslamian S, Gandomkar A, Marani-Barzani M, Amoushahi-Khouzani M, Majidifar Z, Rajaei-Rizi F, Kazemi M, P. Singh V, Dehghan SH, Shirvani-Dastgerdi H.R, Norouzi H, Ostad-Ali-Askari K. 2017, A Proper Way to Install Trapezoidal Flumes for Measurements in Furrow Irrigation Systems. International Journal of Research Studies in Agricultural Sciences (IJRSAS), 3(7): 1-5. 
[35] Dehghan Sh, Kamaneh S.A.A., Eslamian S, Gandomkar A, Marani-Barzani M, Amoushahi-Khouzani M, Singh V.P., Ostad-Ali-Askari K. 2017, Changes in Temperature and Precipitation with the Analysis of Geomorphic Basin Chaos in Shiraz, Iran. International Journal of Constructive Research in Civil Engineering (IJCRCE), 3(2): 50-57.

[36] Eslamian S, Mirabbasi-Najafabadi R, Ostad-Ali-Askari K. Advance Engineering Statistics (Simulation and Modeling of Uncertainty and Sensitivity Analysis). Kankash Publisher. First Edition, 2017. ISBN: 978600-136-359-7. Isfahan, Iran.

[37] Ostad-Ali-Askari K, Shayannejad M. 2016, FLOOD ROUTING IN RIVERS BY MUSKINGUM'S METHOD WITH NEW ADJUSTED COEFFICIENTS. International Water Technology Journal, IWTJ, 6(3): 189-194.

[38] Godarzi A, Eslamian S, Ostad-Ali-Askari K. Water in Literature Aspects (Social and Cultural Aspects). Publication of Tehran Municipality. First Edition, 2016. ISBN: 978-600-439-096-5. Tehran, Iran.

[39] Ostad-Ali-Askari K, Eslamian S, Shayannejad M, et al. Groundwater Hydrodynamic. Horoufchin Publisher. First Edition, 2016. ISBN: 978-600-7419-53-3. Isfahan, Iran.

[40] Ostad-Ali-Askari K, Shayannejad M, Ghorbanizadeh-Kharazi H. 2017, Artificial Neural Network for Modeling Nitrate Pollution of Groundwater in Marginal Area of Zayandeh-rood River, Isfahan, Iran. KSCE Journal of Civil Engineering, 21(1):134-140. Korean Society of Civil Engineers. DOI 10.1007/s12205-016-0572-8.

[41] Shayannejad M, Ostad-Ali-Askari K, Ramesh A, Singh V.P., Eslamian S. 2017, Wastewater and Magnetized Wastewater Effects on Soil Erosion in Furrow Irrigation. International Journal of Research Studies in Agricultural Sciences (IJRSAS), 3(8): 1-14. http://dx.doi.org/10.20431/2454-6224.0308001.

[42] Shayannejad M, Soltani-Toudeshki A.R, Arab M.A, Eslamian S, Amoushahi-Khouzani M, MaraniBarzani M, Ostad-Ali-Askari K. 2017, A Simple Method for Land Grading Computations and its Comparison with Genetic Algorithm (GA) Method. International Journal of Research Studies in Agricultural Sciences (IJRSAS), 3(8): 26-38.

[43] Eslamian S, Ostad-Ali-Askari K, Soltani M. 2017, Climate Variability: Integration of Renewable Energy into Present and Future Energy Systems in Designing Residential Buildings. International journal of Rural Development, Environment and Health Research(IJREH), 1(2): 18-30.

[44] Shayannejad M, Ostad-Ali-Askari K, Eslamian S, et al. 2017, Flow Hydraulic Investigation of the Wastewater on the Soil and Magnetic Field Effects in This Field. International Journal of Constructive Research in Civil Engineering (IJCRCE), 3(3): 1-15.

[45] Shayannejad M, Eslamian S, Singh V.P., Ostad-Ali-Askari K, et al. 2017, Evaluation of Groundwater Quality for Industrial Using GIS in Mountainous Region of Isfahan Province, Koh-Payeh, Isfahan, Iran. International Journal of Constructive Research in Civil Engineering (IJCRCE), 3(3): 24-37.

[46] Eslamian, S. S., 2009, Basin Ecology and Environment (BEE), International Journal of Ecological Economic \& Statistics, Ed., Special Issue Volume, CESER, Vol. 13, No. W09, 1-99.

[47] Gohari, A., Zareian, M. J., Eslamian, S., Nazari, R. 2017, Interbasin Transfers of Water: Zayandeh-Rud River Basin, Ch. 32 in Handbook of Drought and Water Scarcity, Vol. 2: Environmental Impacts and Analysis of Drought and Water Scarcity, Ed. by Eslamian S. and Eslamian F., Francis and Taylor, CRC Press, USA, 619-630.

[48] Goodarzi, E., Ziaei, L. and Eslamian, S., 2015, Recycled Water in Basin and Farm Scales, Urban Water Reuse Handbook, Ch. 65, Ed. By Eslamian, S., Taylor and Francis, CRC Group, 855-858.

[49] Kouhestani, S., Eslamian, S.S., Abedi-Koupai, J. and Besalatpour, A.A., 2016. Projection of climate change impacts on precipitation using soft-computing techniques: A case study in Zayandeh-rud Basin, Iran. Global and Planetary Change, No. 144, 158-170.

[50] Fathian, F., Dehghan, Z.., Eslamian, S., 2016, Evaluating the impact of changes in land cover and climate variability on streamflow trends (case study: eastern subbasins of Lake Urmia, Iran), J. Hydrology Science and Technology, Vol. 6, No. 1, 1-26.

[51] Yousefi, N., Safaee, A., Eslamian, S., 2015, The Optimum Design of Flood Control System Using Multivariate Decision Making Methods (Case Study: Kan River Catchment Basin, Iran), Journal of Flood Engineering, Vol. 6, No. 1, 63-82.

[52] Farshad F., Dehghan, Z., Eslamian, S., H. Bazrkar, 2015, Trends in hydrologic and climatic variables affected by four variations of Mann-Kendall approach in Urmia Lake basin, Iran, Hydrological Sciences Journal, DOI:10.1080/02626667.2014.932911.

[53] Bazrkar, M.H., Tavakoli-Nabavi, E., Zamani, N. and Eslamian, S., 2013, System dynamic approach to hydro-politics in Hirmand transboundary river basin from sustainability perspective, Int. J. Hydrology Science and Technology, Vol. 3, No. 4, 378-398. 
[54] Zamani Nuri, A., Farzaneh, M. R., Fakhri, M., Dokoohaki, H., Eslamian, S. and Khordadi, M. J., 2013, Assessment of future climate classification on Urmia Lake basin under effect of climate change, Int. J. Hydrology Science and Technology, Vol. 3, No. 2, 128-140.

[55] Galoie, M., Zenz, G. and Eslamian, S., 2013, Determining the high flood risk regions using a rainfallrunoff modeling in a small basin in catchment area in Austria, Journal of Flood Engineering, Vol. 4, No. (1-2), 9-27.

[56] Galoie, M., Zenz, G. and Eslamian, S., 2013, Application of L-moments for IDF determination in an Austrian basin, Int. J. Hydrology Science and Technology, Vol. 3, No. 1, 30-48.

[57] Gohari, A., Eslamian, S., Abedi-Koupaei, J., Massah-Bavani, A., Wang, D., Madani, K., 2013, Climate change impacts on crop production in Iran's Zayandeh-Rud River Basin. Science of The Total Environment, Vol. 442, 405-419.

[58] Abdolhosseini, M., Eslamian, S., Mousavi, S. F., 2012, Effect of climate change on potential evapotranspiration: a case study on Gharehsoo sub-basin, Iran, Vol. 2 No. 4, 362-372.

[59] Alaghmand, S., Bin Abdullah, R., Abustan, I. and S. Eslamian, 2012, Comparison between capabilities of HEC-RAS and MIKE11 hydraulic models in river flood risk modeling (a case study of Sungai Kayu Ara River basin, Malaysia), International Journal of Environmental Science and Technology, Vol. 2, No. 3, 270-291.

[60] Chavoshi Borujeni, S., Sulaiman, W. N. A. and S. S. Eslamian, 2010, Regional Flood Frequency Analysis Using L-Moments for North Karoon Basin Iran, Journal of Flood Engineering, Vol. 1, No. 1, 67-76.

[61] Eslamian, S. S. and M. J. Khordadi, 2009, Comparing Rainfall and Discharge Trends in Karkhe Basin, Iran, International Journal of Ecological Economics \& Statistics (IJEES), Vol. 15, No. F09, 114-122.

[62] Eslamian, S. S., 2009, Editorial: Frontiers in Ecology and Environment, International Journal of Ecological Economic \& Statistics, Special Issue on Basin Ecology and Environment (BEE), Vol. 13, No. W09, 1-6.

[63] Nosrati, K., Eslamian, S. S., Shahbazi, A., Malekian, A. and M. M. Saravi, 2009, Application of Daily Water Resources Assessment Model for Monitoring Water Resources Indices, International Journal of Ecological Economic \& Statistics, Special Issue on Basin Ecology and Environment (BEE), Vol. 13, No. W09, 88-99.

[64] Matouq, M., Amarneh, I. A., Kloub, N., Badran, O., Al-Duheisat, S. A. and S. S. Eslamian, 2009, Investigating the Effect of Combustion of Blending Jordanian Diesel Oil with Kerosene on Reducing the Environmental Impacts by Diesel Engine, International Journal of Ecological Economic \& Statistics, Special Issue on Basin Ecology and Environment (BEE), Vol. 13, No. W09, 79-87.

\section{AUTHORS' BIOGRAPHY}

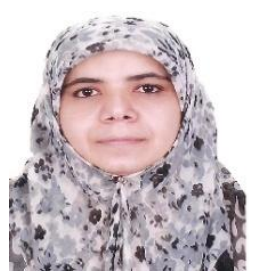

Maryam Marani-Barzani, Department of Geography, University of Malaya (UM),50603 Kuala Lumpur, Malaysia. Member of Suggestion Committee in Ministerial of Education in Iran(2002-2007).Member of Research on Heat Sink Capability of Inland Water Resources for Thermal Power Plants in Peninsular Malaysiaproject (TNBR)(2014-2015).Member of Board Trustees at Consultant Engineering Company (Sharsazan Zendeh Rood) in Iran.(2015-peresent).

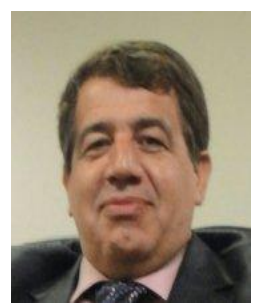

Professor Saeid Eslamian, is a full professor of water system engineering in the Department of Water Engineering at Isfahan University of Technology, Iran, where he has been since 1995. He received his PhD from Civil and Environmental Engineering School, University of New South Wales, Sydney, Australia, under the supervision of Professor David Pilgrim. His research focuses mainly on water resources planning, management, and sustainability and statistical and environmental hydrology in a changing climate. Formerly, he was a visiting professor at Princeton University, New Jersey, and University of ETH Zurich, Switzerland. On the research side, he started a research partnership in 2014 with McGill University, Montreal, Quebec, Canada. He has contributed to more than 600 publications in journals, books, or as technical reports. $\mathrm{He}$ is the founder and chief editor of both the International Journal of Hydrology Science and Technology (Scopus, Inderscience) and the Journal of Flood Engineering. Professor Eslamian is also associate editor of the Journal of Hydrology (Elsevier) and Ecohydrology and Hydrobiology (Elsevier). He has authored more than 150 book chapters and books. Recently, Professor Eslamian published eight handbooks with Taylor \& Francis Group (CRC Press) as chief editor: a three-volume Handbook of Engineering Hydrology (2014), Urban Water Reuse Handbook (2015), a three-volume Handbook of Drought and Water Scarcity (2017), and Underground Aqueducts Handbook (2016). 
Mahboubeh Amoushahi-Khouzani, Water Engineering Department, Science and Research Branch, Islamic Azad University, Tehran, Iran.

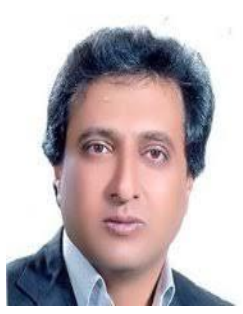

Dr. Amir Gandomkar, Department of Geography, Najafabad Branch, Islamic Azad University, Najafabad, Iran.

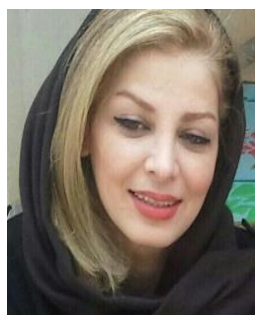

Foroozan Rajaei-Rizi, Water Engineering Department, Shahrekord University, Shahrekord, Iran.

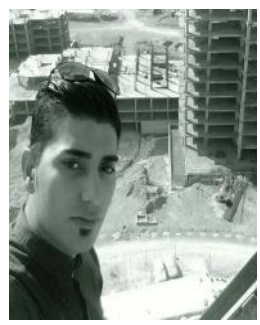

Masoud Kazemi, M.Sc. student of Civil Engineering, Civil Engineering Department, Najafabad Branch, Islamic Azad University, Iran. He has been an expert in various projects of Civil Engineering and technical software such as AutoCAD and MATLAB ${ }^{\circledR}$ programming.

Shahide Dehghan, Department of Geography, Najafabad Branch, Islamic Azad University, Najafabad, Iran.

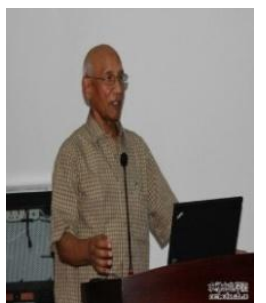

Professor Vijay P. Singh, Ph.D., D.Sc., D. Eng. (Hon.), Ph.D. (Hon.), D.Sc. (Hon.), P.E., P.H., Hon. D. WRE, Academician (GFA), Distinguished Professor, Regents Professor, Caroline and William N. Lehrer Distinguished Chair in Water Engineering

President, FARA, President, G.B.S. Board, Editor-in-Chief, Water Science and Technology Library Bookseries, Editor, Global Water Resources Book Series, Editor-in-Chief, Journal of Ground Water Research, Editor-in-Chief, Open Agriculture, Editor, Journal of Agricultural Research, Department of Biological and Agricultural Engineering \&Zachry Department of Civil Engineering, Texas A and M University. is a professor of agro-meteorology and remote sensing, University of Thessaly, Volos Hellas; president of the Council of the Agricultural University of Athens, Hellas; and professor and founding director of the Laboratory of Agro-meteorology, University of Thessaly, Volos Hellas (1991-2011). He has done his postgraduate studies in meteorology (Athens, 1972) and hydrological engineering (University of Delft, 1974) and his $\mathrm{PhD}$ in civil engineering (University of Waterloo, Canada, 1982). He has a longstanding research record in agro-meteorology, agro-hydrology, remote sensing, modeling, environmental hazards, risk assessment, climate variability/change. He is the author or co-author in over 290 refereed publications and technical and scientific publications, member of editorial boards and reviewer in international scientific journals, editor or co-editor in over 20 edited publications, and co-author in about 35 book chapters.

Hossein Norouzi, Faculty of Civil Engineering, Maybod Branch, Islamic Azad University, Maybod, Yazd, Iran.

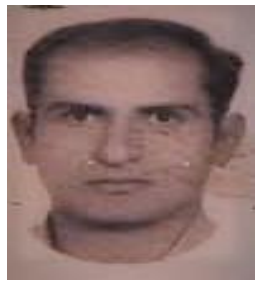

Hamid-Reza Shirvani-Dastgerdi, Department of Civil Engineering, Isfahan (Khorasgan) Branch, Islamic Azad University, Isfahan, Iran. 


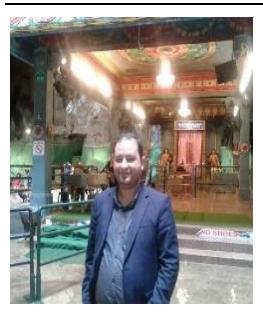

Amin Sadri, Water and Wastewater Company, Isfahan Province, Isfahan, Iran.

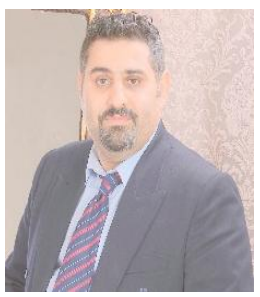

Dr. Kaveh Ostad-Ali-Askari, is a PhD of civil engineering, Department of Water Resources Engineering, Faculty of Civil Engineering. He collaborates as Editorial Board Membership in more than 45 Journals and as reviewers in more than 35 Journals. Currently, Associate, Editor-in-Chief of IJREH. He has contributed to more than 125 publications in Journals, Books and Technical Reports. He was a Visiting Assistant Professor at Canadian University Dubai, and American University in Dubai. On the research side, he started a research partnership in 2017 with Concordia University in Montreal, Quebec, Canada. His topics of interest include Groundwater Hydrology, Irrigation and Drainage Engineering, Sustainable Development and Environmental Assessment, Climate and Integrated and Sustainable Water Resource Management, Water System Engineering, Water Resources Planning, Artificial Neural Network, and Genetic Algorithm. Currently, he is a Faculty Member of the Department of Civil Engineering, Isfahan(Khorasgan) Branch, Islamic Azad University, Iran

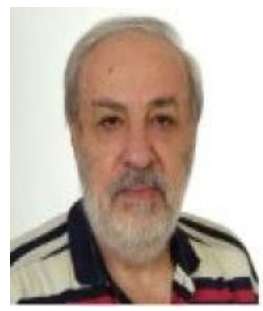

Professor Nicolas R. Dalezios, is a professor of agro-meteorology and remote sensing, University of Thessaly, Volos Hellas; president of the Council of the Agricultural University of Athens, Hellas; and professor and founding director of the Laboratory of Agro-meteorology, University of Thessaly, Volos Hellas (19912011). He has done his postgraduate studies in meteorology (Athens, 1972) and hydrological engineering (University of Delft, 1974) and his $\mathrm{PhD}$ in civil engineering (University of Waterloo, Canada, 1982). He has a longstanding research record in agro-meteorology, agro-hydrology, remote sensing, modeling, environmental hazards, risk assessment, climate variability/change. He is the author or co-author in over 280 refereed publications and technical and scientific publications, member of editorial boards and reviewer in international scientific journals, editor or co-editor in over 15 edited publications, and co-author in about 30 book chapters.

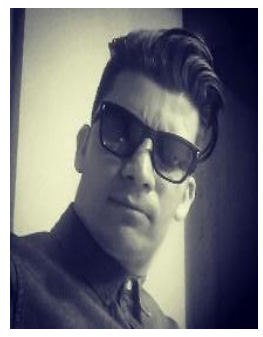

Morteza Soltani, Department of Architectural Engineering, Shahinshahr Branch, Islamic Azad University, Shahinshahr, Iran.

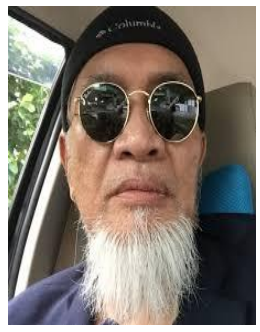

Dr. Khairulmaini Bin Osman Salleh, Department of Geography, University of Malaya (UM), 50603 Kuala Lumpur, Malaysia.

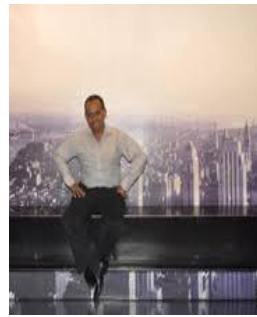

Dr. Yohannes Yihdego, Snowy Mountains Engineering Corporation (SMEC), Sydney, New South Wales 2060, Australia. Geoformation Science and Earth Observation (ITC), University of Twente, the Netherlands. Working at Global Engineering consulting firm in Hydro-Geo-Engineering across Australia, Middle East, Asia, Africa in water, resource, mining, infrastructure, transport, energy, agriculture, landfill, contamination/pollution/remediation, environmental assessments, flood/urban drainage design/modelling, drought, climate change 
Produced hundreds' of Engineering technical -feasibility/ detail design reports \& Published several articles \& book chapters Serving as peer Reviewer \& Editor board member.

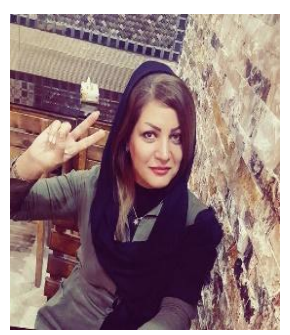

Zahra Askari, Water Engineering Department, Ferdowsi University of Mashhad, Mashhad, Iran.

Citation: Dr. Kaveh Ostad-Ali-Askari et al. (2017). Assessment of Aridity Using Geographical Information System in Zayandeh-Roud Basin, Isfahan, Iran, International Journal of Mining Science (IJMS), 3(2), pp.4961, DOI: http://dx.doi.org/10.20431/2454-9460.0302005.

Copyright: (C) 2017 Dr. Kaveh Ostad-Ali-Askari. This is an open-access article distributed under the terms of the Creative Commons Attribution License, which permits unrestricted use, distribution, and reproduction in any medium, provided the original author and source are credited 